\title{
The surges of Variegated Glacier, Alaska, U.S.A., and their connection to climate and mass balance
}

\author{
O. Eisen, ${ }^{1 *}$ W. D. Harrison, ${ }^{1}$ C. F. Raymond ${ }^{2}$ \\ ${ }^{1}$ Geophysical Institute, University of Alaska Fairbanks, Fairbanks, Alaska 99775-7320, U.S.A. \\ ${ }^{2}$ University of Washington, Geophysics Program, Box 351650, Seattle, Washington 98195-1650, U.S.A.
}

\begin{abstract}
One of the questions still unanswered concerning the surge behavior of glaciers concerns their quasi-periodic occurrence. Some results on the phenomenological connection between local cumulative balance and surge initiation of Variegated Glacier, Alaska, U.S.A., are discussed here. Based on climate data from neighboring weather stations, an empirical relation between precipitation, temperature and local mass balance is established and used to reconstruct the annual balance at a location in the accumulation area back to 1905. Between the last four surges in 1946/47, 1964/65, 1982/83 and 1994/95, the ice-equivalent cumulative balance was $43.5 \mathrm{~m}$ on average, with a $1 \sigma$ error of $1.2 \mathrm{~m}$. Although the existence of a surge level cannot be directly interpreted in physical terms, it explains the variable length of the quiescent periods of Variegated Glacier by variations in the accumulation rate prior to the surge. We use the surge level to hindcast former unobserved surges, to compare the results with other surge datings obtained from photographs and to establish a complete surge history for Variegated Glacier for the 20th century.
\end{abstract}

\section{INTRODUCTION}

Surge-type glaciers oscillate between two stages of motion, the quiescent period and the surge phase. The surge phase, characterized by comparatively fast motion, occurs at quasiperiodic multi-year intervals (Raymond, 1987). Proposed mechanisms for surge initiation consider either a threshold behavior of the underlying sediments (Boulton and Jones, 1979; Clarke and others, 1984; Harrison and others, 1994; Truffer and others, 2000) or the transformation of the basal drainage system from a tunnel to a linked-cavity system (Kamb, 1987). Both mechanisms assume that shear stress plays a major role, which in turn is linked to other properties, like the glacier geometry (Fountain and Walder, 1998). The interrelations among mass balance, ice thickness, glacier geometry and the occurrence of surges have been investigated by several authors for different regions (e.g. Svalbard (Dowdeswell and others, 1995); Medvezhiy glacier, Pamir, Central Asia (Dyurgerov and others, 1985)). In this study we establish an empirical relationship between the variable timing of the surges of Variegated Glacier, Alaska, U.S.A., and the cumulative balance at a point in the accumulation area. This relation is then used to hindcast past surges and compare the datings with the results obtained by other methods.

The surge history of Variegated Glacier, a small mountain glacier near the Alaskan coast (Fig. 1), is well documented and provides a unique century-long record of surge events. Extensive field campaigns were carried out prior to and during the 1983 surge, beginning in 1972. The investigations

\footnotetext{
* Present address: Alfred Wegener Institute for Polar and Marine Research, P.O. Box 120161, D-27515 Bremerhaven, Germany.
}

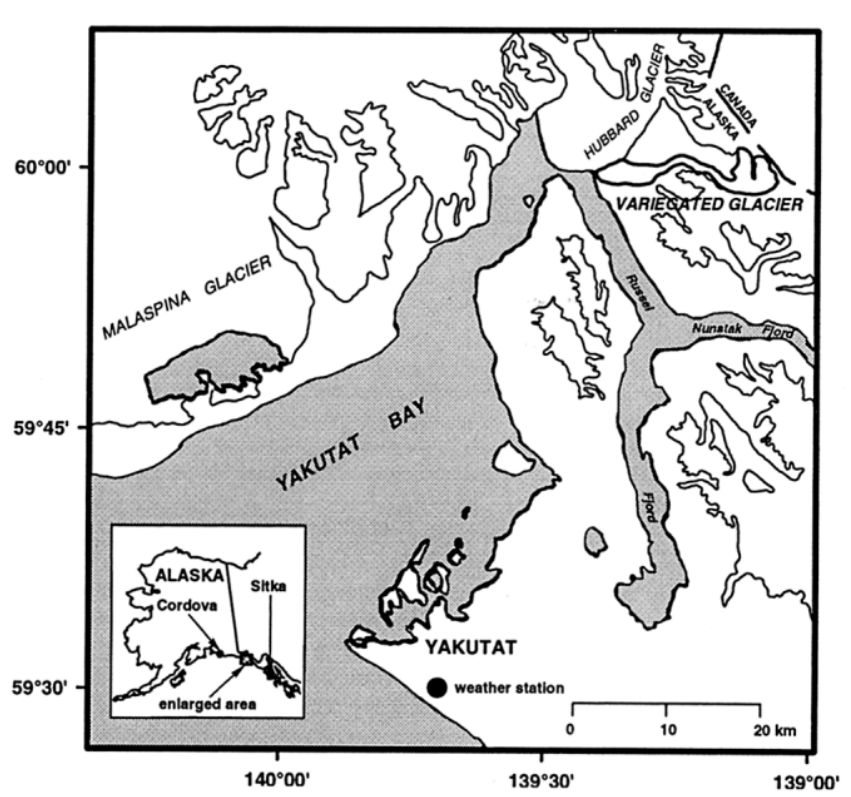

Fig. 1. Location of Variegated Glacier in southeast Alaska. The three weather stations are located near Yakutat (black circle), Cordova and Sitka (arrows in inset).

focused on the development of the glacier before a surge: mainly thickening in the upper part of the glacier and increased surface velocities (Raymond, 1987). The field studies included investigations on annual balance, surface elevation, surface slope, ice motion, bed geometry and temperature, and are summarized in a series of data reports (e.g. Bindschadler and others, 1976; Raymond and others, 1980, 1981). The survey of the 1983 surge led to a better understanding of the mechanisms occurring during a surge (Kamb and others, 1985).

To establish a relation between the mass balance and the occurrence of surges, coverage needs to extend over several 


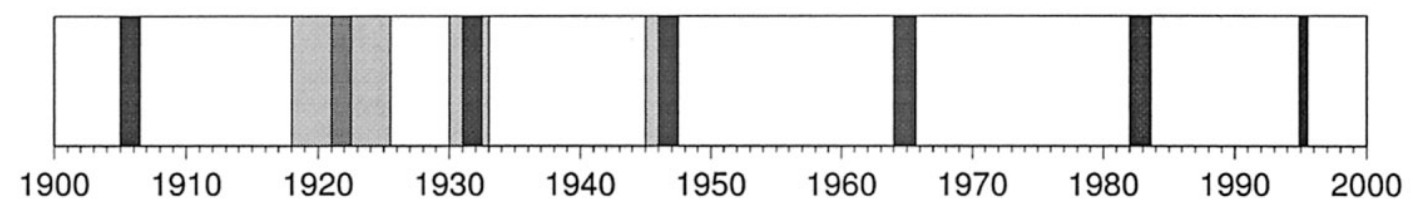

Fig. 2. Compiled timeline of surge events. The dark bars indicate the active surge periods (from the onset of a surge to its termination) that are known reasonably well, determined from observations and hindcasting. The medium shaded bar for the 1922 surge represents the best estimate for the dating from hindcasting, as described in the text. The light shaded bars for the 1922, 1933 and 1947 surges indicate the possible period for the dating of a surge event due to missing observations and uncertainties in hindcasting.

surge cycles. As no long-term records of balance measurements are available for Variegated Glacier, it is necessary to reconstruct the annual balance using meteorological data. The statistical approach described in detail by Letréguilly (1988) is used to determine the mass balance from climate data. Due to missing balance data the correlation of annual balance and climate variables is restricted to local annual balance measurements at a site in the upper part of the glacier. With meteorological data from the weather station in Yakutat, a regression is carried out to extrapolate the annual balance at a point in the accumulation area from 1947 to 1998. Climate data from Sitka and Cordova are used to reconstruct gaps in the meteorological record from Yakutat prior to 1936, resulting in a local annual balance series back to 1905. The connection between surge events and local annual balance series is examined here.

\section{DATABASE}

\section{History of surges}

Several authors have compiled and updated the surge history of Variegated Glacier (Tarr and Martin, 1914; Post, 1969; Bindschadler and others, 1976; G. Bender, personal communication, 1983; J. DeMaille-Gorda, personal communication, 1996; Lawson, 1997). Surges are reasonably well documented in 1905/06, shortly before 1933 and 1948, and in 1964/65, 1982/ 83 and 1995. An unobserved surge probably occurred about 1920. The results are summarized in Figure 2.

The 1982/83 surge was observed in detail and is described by Kamb and others (1985). It took place in two phases, JanuaryJuly 1982 and October 1982-July 1983. The most recent surge started in fall or winter 1994 and ended in June 1995. Later photography suggests that the surge may have reinitiated 2 or 3 years later. The duration of the other surges is not known. Although only two surges were observed in detail, datings from photographs suggest that surges take 1-2 years on average, usually followed by a $12-18$ year quiescent period. The active surge phase of the 1983 surge lasted 2 years, as probably did the 1965 and 1906 surges. As observed during the 1983 surge, it seems possible that a surge can stop for a period before being rejuvenated. The exceptional behavior of the 1995 surge in comparison to the other known surges is still under investigation.

In the following sections the different surges are referred to by the year of the final surge termination (e.g. 1983 for the 1982/83 surge). The surge interval is then defined as the period between two surge endings.

\section{Mass-balance data}

Mass balance was measured along the glacier center line using buried magnets as markers (Harrison and others, 1979) during the 10 year interval 1973-82 (Bindschadler and others, 1976; Raymond and others, 1980, 1981; and unpublished field data). The measurements were made each year in the first part of September, near the end of the ablation season, and give approximate annual balances. The equilibrium line usually runs in a west-east direction, almost parallel to the glacier, with a typical elevation of $1000 \mathrm{~m}$ at the center line (Fig. 3), but shows variations of up to $300 \mathrm{~m}$ from year to year. As the onset of a surge takes place in the upper glacier, between $\mathrm{km} 3$ and 6 in the accumulation area (Raymond, 1987), local massbalance data from the accumulation area are believed to be more useful for a correlation with surge occurrences than the mass balance of the entire glacier. The most complete data

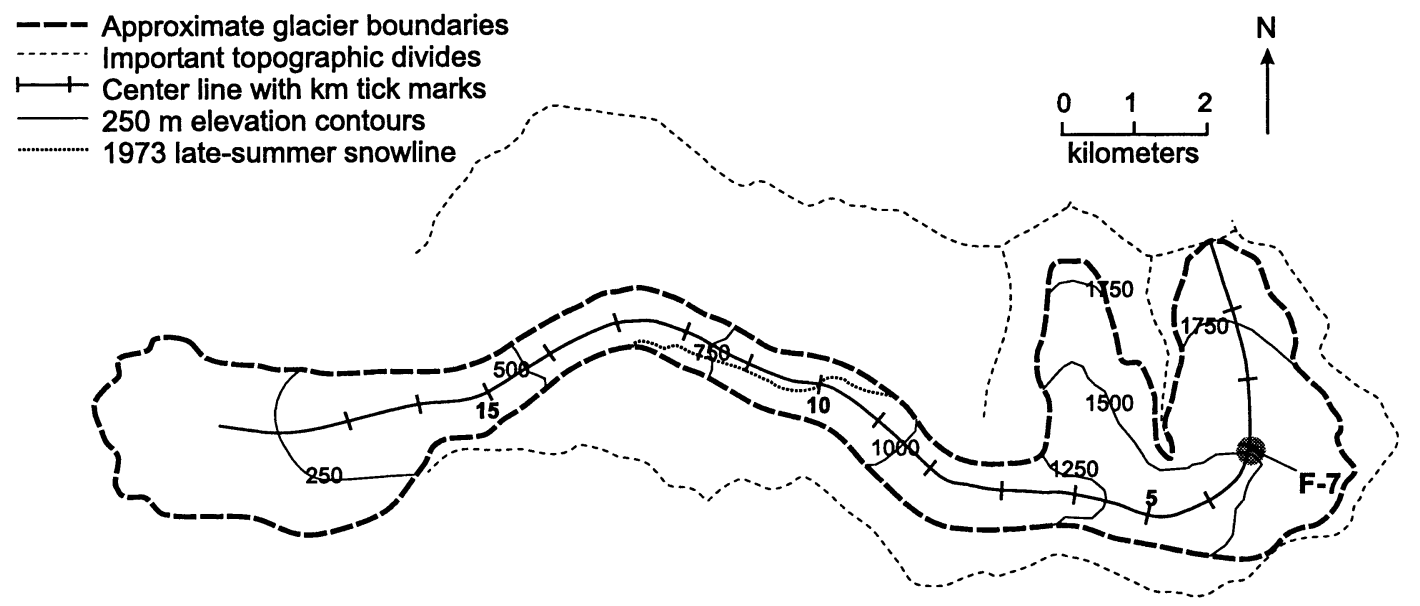

Fig. 3. Map of Variegated Glacier with center-line coordinate system and distance from glacier head (ticks in km). In the centerline coordinate system, site $F-7$ is located near $\mathrm{km} 3$ at an elevation of about $1500 \mathrm{~m}$ (grey shaded circle). Direction of glacier flow is from east to west, i.e. from right to left. 
Table 1. Measured and estimated annual mass balance at $F-7$

\begin{tabular}{ccc}
\hline Year & $\begin{array}{c}\text { Measurements } \\
\text { mice equiv. }\end{array}$ & $\begin{array}{c}\text { Regression } \\
\text { m ice equiv. }\end{array}$ \\
\hline 1973 & 2.8 & 2.1 \\
1974 & 1.1 & 1.1 \\
1975 & $(4.3)$ & 4.0 \\
1976 & $(2.3)$ & 2.0 \\
1977 & 4.6 & 5.0 \\
1978 & 1.4 & 1.7 \\
1979 & 2.6 & 2.9 \\
1980 & 3.6 & 3.0 \\
1981 & 3.0 & 3.2 \\
1982 & 1.7 & 2.1 \\
& & \\
\hline
\end{tabular}

Notes: The measurements were carried out in the first half of September and give approximate annual balances at $\mathrm{F}-7$. The values in parentheses are estimated as described in the text. The estimated annual balance at $\mathrm{F}-7$ in the third column is obtained from the regression Equation (3).

from the accumulation area are from site $\mathrm{F}-7$, located $3.0 \mathrm{~km}$ along the center line from the head of the glacier (Fig. 3). Missing data for 1975 and 1976 were estimated by establishing a correlation between the local annual balances at $\mathrm{F}-7$ and $\mathrm{F}+9$, located at $\mathrm{km} 7.0$ along the center line. The resulting annual balance series at $\mathrm{F}-7$ is shown in Table 1 .

\section{Meteorological data}

Data from three weather stations were used: Yakutat, $60 \mathrm{~km}$ southwest of the glacier; Cordova, about $360 \mathrm{~km}$ west; and Sitka, $410 \mathrm{~km}$ southeast (Fig. 1). All are near the coast and close to sea level. Although other weather stations are also available, they are disregarded due to poor site continuity (Haines and Juneau), too short (Juneau Airport) or discontinuous records (Juneau) (personal communication from S. A. Bowling, 1997). The Yakutat climate record starts in 1917. Data are missing during the periods 1926-36 and 1940-43. The weather station was moved several times in the first part of the 20th century (personal communication from S. A. Bowling, 1997; NOAA, 1999). The last change in the station location took place in 1948 when it was moved $0.5 \mathrm{~km}$. Sitka Magnetic Station was established in 1829 and closed down in 1989. Several moves took place between 1930 and 1942, some of them not documented in detail. The Cordova weather station started recording in 1909. Data are partly lacking before 1942. Several station moves took place before 1989. Changes in instrumentation took place at all three stations. The primary data consist of the monthly precipitation $(P)$ and the monthly mean of the daily minimum $(t)$ and maximum $(T)$ temperature for each of the three stations (NOAA, 1999).

\section{RELATION BETWEEN LOGAL ANNUAL BALANGE AND GLIMATE}

In this section the goal is first to find the best correlation between the measured annual balance at $\mathrm{F}-7$ and the different climate parameters, and second to use a regression to estimate the annual balance at $\mathrm{F}-7$ from the climate data.

\section{Correlation of climate and measured annual balance at $\mathrm{F}-7$}

In order to estimate the annual balance at a point on a glacier from weather records, the connection between precipitation, temperature and the local annual balance must be determined. There have been many studies of the correlation between observed mass balances and climate parameters (e.g. Martin, 1974; Hoinkes and Steinacker, 1975; Tangborn, 1980; Braithwaite, 1985; Hanson, 1987; Rabus and Echelmeyer, 1998). Letréguilly (1988) compared several mass-balance series of three Canadian mountain glaciers in different parts of the Rocky Mountains with the meteorological records of nearby weather stations. We follow her statistical approach because it was successfully applied in a nearcoastal environment (Sentinel Glacier, British Columbia) which seems similar to that of Variegated Glacier. Her approach involves rearranging the primary meteorological data as follows:

Summing the precipitation series over several months results in the series $P_{i-j}$, where $i$ is the first and $j$ the last month of the sum. For example, $P_{10-4}$ or $P_{\text {October-April }}$ is the sum of the monthly precipitation from October to April. The monthly means of the minimum and maximum temperature are averaged over several months, resulting in the temperature series $t_{i-j}$ and $T_{i-j}$, respectively, where $i$ and $j$ indicate the first and last month of the averaging period. Different sets of $P_{i-j}$ are computed for $i$ varying from month 8 (August) to 12 (December) and $j$ from month 3 (March) to 5 (May). For $t_{i-j}$ and $T_{i-j}, i$ and $j$ are varied from month 4 (April) to 6 (June), and $j$ from month 8 (August) to 10 (October). This gives fifteen precipitation series, nine minimum temperature series and nine maximum temperature series for all three weather stations. The series are then statistically correlated with the annual balance at $\mathrm{F}-7$.

It is assumed that the local annual balance, precipitation and temperature, described by three variables $y, x_{1}$ and $x_{2}$, follow a bilinear relation of the form

$$
y=m_{0}+m_{1} x_{1}+m_{2} x_{2} .
$$

The multiple correlation coefficient $R_{\text {multi }}$ for the three variables is given by

$$
R_{\text {multi }}=\sqrt{\frac{R_{x_{1} y}^{2}+R_{x_{2} y}^{2}-2 R_{x_{1} x_{2}} R_{x_{1} y} R_{x_{2} y}}{1-R_{x_{1} x_{2}}^{2}}} .
$$

$R_{x y}$ is the correlation coefficient of the simple linear correlation between the variables indicated in the subscript (Martin, 1974). The multiple correlation coefficient is calculated for all 270 combinations of $P_{i-j}$ with $t_{i-j}$ and $T_{i-j}$ of the Yakutat record and the measured annual balance at $\mathrm{F}-7$ for the period 1973-82. The statistical analysis confirms the expected result, i.e. that winter precipitation and summer temperatures are most important for the mass balance of Variegated Glacier. For several combinations the correlation coefficient is $>0.9$, representing the fact that monthly averaged minimum, maximum and average temperatures are closely correlated. The combination of the two variables $P_{10-4}$ and $t_{5-9}$ results in the best correlation with the annual balance at $\mathrm{F}-7$ $\left(R_{\text {multi }}=0.94\right)$. They explain $88 \%$ of the variance (precipitation $66 \%$, minimum temperature $22 \%$ ). We therefore use only the $P_{10-4}$ and $t_{5-9}$ time series for further calculations.

\section{Estimation of annual mass balance at F-7 from climate record}

The coefficients $m_{i}$ of the bilinear expression in Equation (1) are calculated from a least-squares fit of the 10 year long 


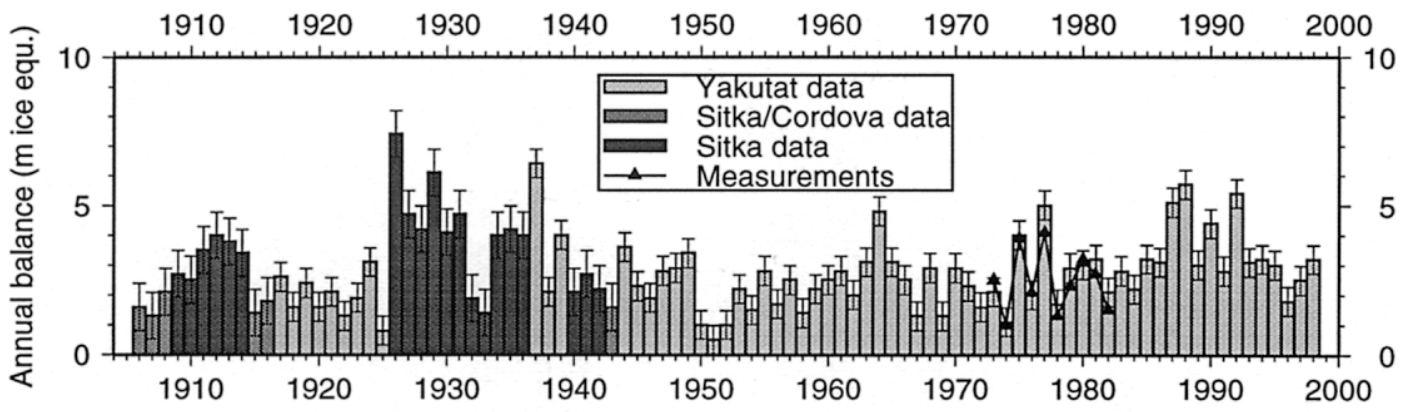

Fig. 4. Estimated local annual balance at site F-7, 1906-96. The measured annual balance at F-7 for the years 1973-82 is shown as triangles. The different grey scales indicate the meteorological-station data used to reconstruct the missing data from Yakutat as described in the text.

measured annual balance series at $\mathrm{F}-7$ and the corresponding Yakutat precipitation and temperature series, $P_{10-4}$ and $t_{5-9}$, respectively. This leads to the regression formula

$$
\begin{aligned}
b_{\mathrm{a}}^{\mathrm{YAK}}(\mathrm{F}-7)= & -1.29+\left(1.66 \times 10^{-3} P_{10-4}\right) \\
& -\left(6.2 \times 10^{-2} t_{5-9}\right)
\end{aligned}
$$

for the estimated annual balance at $\mathrm{F}-7, b_{\mathrm{a}}^{\mathrm{YAK}}(\mathrm{F}-7)$. With $P_{10-4}$ in $\mathrm{mm}$ and $t_{5-9}$ in ${ }^{\circ} \mathrm{C}, b_{\mathrm{a}}^{\mathrm{YAK}}(\mathrm{F}-7)$ is given in $\mathrm{m}$ ice equivalent. For the sake of brevity, all mass-balance values are given in ice-equivalent meters and abbreviated with $\mathrm{m}$.

\section{Extrapolation of the annual balance at F-7}

To extrapolate the annual balance series at $\mathrm{F}-7$ back to 1943 , we exclusively use the Yakutat climate data in the regression Equation (3). The missing Yakutat variables $P_{10-4}$ and $t_{5-9}$ before 1943, necessary to estimate the annual balance at $\mathrm{F}-7$, are estimated from the Sitka and Cordova climate record.

To reconstruct the Yakutat series from the other two weather stations, regressions are derived from a leastsquares fit for 43 data points consisting of the 1947-89 $P_{10-4}$ and $t_{5-9}$ series for all three stations. This period is chosen because the data from each of the stations are least influenced by station moves and changes in instrumentation after 1947, and Sitka Magnetic Station was shut down in 1989. To decide which regression is the most suitable, a multiple correlation coefficient and two simple correlation coefficients are calculated (see Appendix). The best correlation is achieved with the bilinear regression. It is therefore used to calculate the missing Yakutat minimum temperature and precipitation series. In those years when Cordova data are missing, the linear regression with the Sitka record is used to estimate the Yakutat data. In 1908 no precipitation and in 1909 no temperature data are available from all three stations. In these two years the mean of the extrapolated Yakutat data series is taken to represent the missing values.

Considering the database used for the extrapolation, the length of the measured annual balance series at $\mathrm{F}-7$, from which the regression Equation (3) is derived, and the length of the reconstructed annual balance series at $\mathrm{F}-7$, three major questions addressing the accuracy of the extrapolated time series arise: (i) How do the annual balance values at F-7 estimated from Equation (3) agree with the measured values from 1973 to 1982? (ii) How stable is the regression with time if only Yakutat climate data are used? and (iii) What influence does the use of different weather stations prior to 1943 have on the accuracy and errors of the extrapolated series?

For the sake of clarity, the answers to these questions are derived in detail in the Appendix. Here, we briefly present the main results: (i) The rms error between the estimated and measured annual balance at $\mathrm{F}-7$ for the period $1973-82$ is $0.48 \mathrm{~m}, 18 \%$ of the mean annual balance at $\mathrm{F}-7$. (ii) Because the annual balance at $\mathrm{F}-7$ during the period of measurements shows a large variance, the regression Equation (3) is assumed to be stable in time. (iii) The errors assigned to the extrapolated annual balance series at $\mathrm{F}-7$ are $0.48 \mathrm{~m}$ for the values estimated from the Yakutat record and $0.78 \mathrm{~m}$ where Cordova and/or Sitka records are used (Fig. 4). Using Equation (3) together with the complete Yakutat climate record, the annual balance from 1905 to 1999 at F-7 (Fig. 4) is available to investigate the relation between local annual balance and surges.

\section{LOGAL ANNUAL BALANGE AND SURGE BEHAVIOR}

The connection between the cumulative balance at $\mathrm{F}-7$ and the occurrence of surges is examined in this section. The established relation is then used to hindcast surge dates for the first half of the 20th century.

\section{Cumulative balance between surges}

Using the known surge history for the second half of the 20 th century, it is possible to accumulate the annual balance at $\mathrm{F}-7$ for three periods between surges after 1947 to obtain three cumulative balances for $\mathrm{F}-7$. As interval boundaries for the accumulation we use the year following the surge initiation and the year of the beginning of the next surge. Note that this is different from the surge-date nomenclature. This means, for example, that the cumulative balance from 1965 to 1982 is relevant for the 1983 surge, and the sum from 1983 to 1994 for the 1995 surge. The development of the cumulative balance for the periods prior to the 1965, 1983 and 1995 surges is shown for each year after the initiation of the previous surge in Figure 5. Due to the lack of supplementary information, we choose 1946 to be the year of the initiation of the 1947 surge.

In this manner, we determine the total cumulative balance in each of the three surge intervals. An estimate of the errors of the cumulative balances may be obtained by assuming independent errors for the annual balance series at $\mathrm{F}-7$. For the given surge-history scenario the cumulative balances and the corresponding errors for the three periods are $41.3 \pm 2.1 \mathrm{~m}$ from 1947 to $1964,45.0 \pm 2.1 \mathrm{~m}$ prior to the 1983 surge and $44.1 \pm 1.7 \mathrm{~m}$ before the last surge in 1995 (Table 2). The error-weighted mean cumulative balance of these three surge intervals equals $43.5 \pm 1.2 \mathrm{~m}$. Although the standard devation of the mean of $1.2 \mathrm{~m}$ corresponds to only $2.7 \%$ of the mean cumulative balance (the $1 \sigma$ error), the use of just three data points increases the uncertainty. 


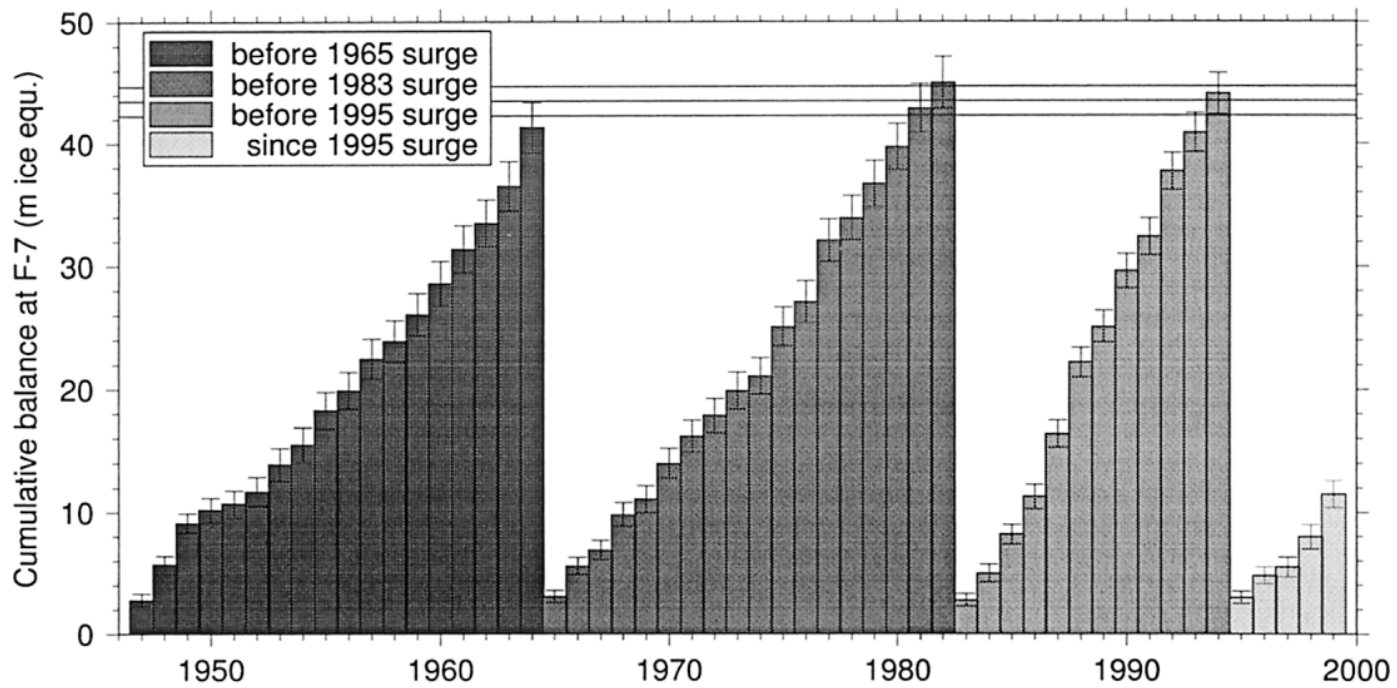

Fig. 5. Estimated cumulative annual balance series at $F-7$ prior to each surge with $1 \sigma$ error intervals. The average of the cumulative balance between the surges (43.5 m ice equivalent) and the interval within one standard deviation of the mean (1.2 $\mathrm{m}$ ) are indicated by the solid and dashed lines, respectively.

In $95 \%$ of cases the standard deviation of the mean is $<7.5 \mathrm{~m}$ (Table 3), or roughly $17 \%$ of the mean cumulative balance.

To evaluate the influence of our choice of the accumulation interval on the average cumulative balance, we shift the accumulation interval by 1 year, starting in the year after the previous surge ends. Neither the mean cumulative balance nor the associated standard deviation of the mean is affected by this change.

\section{Hindcasting of surges}

Only the last three surges of Variegated Glacier were used to estimate the average cumulative balance between surges of $43.5 \mathrm{~m}$. We now use this "surge level" to hindcast the surges before 1947 by accumulating the annual balance at F-7 backward in time. For this, the interval boundaries are reversed. That is, the accumulation starts 1 year before the start of the (later) surge and ends in the year of the termination of the (previous) surge.

Starting in 1946, values close to the surge level are reached in $1933(42.6 \mathrm{~m})$ and 1932 (44.5 m). As the year of initiation of the 1947 surge is not known for certain, we start a second hindcasting period in 1945 . A cumulative balance of $42.6 \mathrm{~m}$ is then reached in 1932 . Our best estimate for the termination of the pre-1933 surge is 1932, with an accuracy

Table 2. Surge intervals and cumulative balance at $F-7$

\begin{tabular}{lccc}
\hline Period & Interval & Accumulation & $\begin{array}{c}\text { Mean annual balance } \\
\text { years }\end{array}$ \\
& mice equiv. & mice equiv. \\
\hline $1906-21$ & 16 & $38.5 \pm 2.8$ & 2.4 \\
$1922-31$ & 10 & $38.3 \pm 2.0$ & 3.8 \\
$1932-46$ & 15 & $44.5 \pm 2.6$ & 3.0 \\
$1947-64$ & 18 & $41.3 \pm 2.1$ & 2.3 \\
$1965-82$ & 18 & $45.0 \pm 2.1$ & 2.5 \\
$1983-94$ & 12 & $44.1 \pm 1.7$ & 3.7
\end{tabular}

Notes: The accumulation period (first column) starts in the year of the surge termination and lasts until the beginning of the next surge. The length of a surge interval (second column) is the period between two surge terminations. The $1 \sigma$ errors have been calculated for the surge scenario described in the text. of 1 year, as for both hindcasting periods a value close to the surge level is reached in this year. Further accumulating the annual balance at F-7 backward in time from 1932 leads to a value close to the surge level in 1920 (42.1 m) or 1919 $(44.6 \mathrm{~m})$. On the other hand, accumulating forward in time from 1906, a cumulative balance of $41.6 \mathrm{~m}$ is reached in 1924 and $44.7 \mathrm{~m}$ in 1925. Both cumulative balances before and after this unknown surge are closest to the surge level if it is dated to 1922: $38.5 \mathrm{~m}$ in the period 1906-21 and $38.3 \mathrm{~m}$ in the period 1922-31. The surge interval thus has a length of 16 years before and 10 years after the 1922 surge (Table 2).

Together with the observations, the hindcasting of the surge events seemingly provides a complete surge history of Variegated Glacier for the 20th century (Fig. 2). Using all six cumulative balances given in Table 2 , the error-weighted mean surge level changes to $42.4 \mathrm{~m}$ with a standard deviation of the mean of $0.8 \mathrm{~m}$. As six values are now involved in the computations, the upper limit for the $95 \%$ confidence interval of the standard deviation of the mean decreases by a factor of four in comparison to the value calculated from the last three surges only (Table 3). Despite the lower accuracy, we will use a surge level of $43.5 \mathrm{~m}$, as the dating of the earlier surges requires several assumptions.

\section{DISGUSSION}

The surges of Variegated Glacier do not occur after equal time intervals but when the cumulative balance at $\mathrm{F}-7$ has reached a well-defined level of $43.5 \mathrm{~m}$. This value is asso-

Table 3. Best estimates for the mean surge level and the $95 \%$ confidence interval for the standard deviation of the mean

\begin{tabular}{lccc}
\hline Period & Intervals & Mean & Std dev. \\
\hline $1947-95$ & 3 & 43.5 & $1.2[0.6,7.5]$ \\
$1906-95$ & 6 & 42.4 & $0.8[0.5,1.9]$
\end{tabular}

Notes: The mean surge level and the standard deviation of the mean are given in ice-equivalent meters. The boundaries of the $95 \%$ confidence interval for the standard deviation of the mean are given in brackets. To estimate the mean surge level from all six surge intervals, the dating of the 1922 surge has to be determined as described in the text. 
ciated with a $1 \sigma$ error of $1.2 \mathrm{~m}$. For $95 \%$ of the time the value should be within an interval of $\pm 7.5 \mathrm{~m}$. This means that it is not certain whether the surge level is a precisely defined physical parameter, or if it is rather a quantity with possible values distributed over a wider range.

The length of the surge intervals and the average annual balances at $\mathrm{F}-7$ in the periods prior to the three surges in 1965, 1983 and 1995 vary substantially. The average annual balances at $\mathrm{F}-7$ in the periods $1947-64$ and $1965-82$ are 2.3 and $2.5 \mathrm{~m}$, respectively; the surge interval is 18 years in both cases (Table 2). Prior to the 1995 surge, however, the average annual balance at $\mathrm{F}-7$ was $3.7 \mathrm{~m}$, i.e. $50 \%$ higher than during the two previous quiescent periods, and the surge interval was 6 years shorter. The existence of a surge level thus explains why the length of the surge interval is determined by the average local annual balance: with a larger average local annual balance, the surge level is reached earlier, resulting in a shorter surge interval.

The dating of surges in the first half of the 20th century, carried out in the last section, provides two opportunities to test the hypothesis that Variegated Glacier starts surging when the cumulative balance in the upper part of the glacier reaches a certain level. First, the cumulative balances of the 1922 and 1932 surges are smaller than for other surges (Table 2), but they still agree reasonably well considering the confidence interval. The varying length of these surge intervals can be explained by the average local annual balance during the pre-surge period (Table 2). Second, the hindcasted 1932 surge corresponds to the dating of a surge just before 1933. Unfortunately, no photographs are available to confirm or reject the 1922 surge event. The connection between mass balance and surge behavior has also been noticed for other glaciers. Dowdeswell and others (1995) showed that the number of actively surging glaciers in Svalbard decreased from 18 to 5 over the period 1936-90. They attribute this change to a negative mass balance in response to an abrupt climate shift. A critical mass balance for surge initiation of Medvezhiy glacier is calculated by Dyurgerov and others (1985), based on climatological data from a nearby weather station and measured mass balances. They explain the varying length of four surge intervals by the different mass balances in quiescent phases. In a recent study, W. Tangborn and R. Soemarmo (personal communication, 2000, http:// www.hymet.com) apply a mass-balance/runoff model to Variegated Glacier. Their results imply that, as well as accumulation, a higher than normal water influx must also occur to initiate a surge. It is remarkable that their threshold value for surge initiation is almost identical to our surge level, although the applied methods are different.

The geometry of the glacier should provide the physical link for the apparent connection between cumulative balance and surge initiation. The observed increase in elevation in the upper glacier and the steepening of the surface slope in the years before the 1983 surge (Raymond, 1987) suggest that the shear stress plays a key role in changing the basal motion of the glacier (Boulton and Jones, 1979; Clarke and others, 1984; Kamb, 1987). In addition to the accumulation, the flow in the upper glacier could also contribute to the formation of a critical geometry. In 1984, a drop in elevation at $\mathrm{F}-7$ of $67 \mathrm{~m}$ compared to 1981 was observed. Although topographic maps are available for other years (e.g. for 1948 (USGS topographic map 1954, part coverage), 1961 (Feher, 1976; USGS topographic map 1964) and 1974 (Feher, 1976)), they are too inaccurate to determine a reasonable surface elevation. An intercomparison of elevations along the center line in the upper glacier reveals systematic differences of $25 \mathrm{~m}$ (Bindschadler and others, 1976), as well as unbiased deviations of up to $40 \mathrm{~m}$ among the different datasets. Furthermore the temporal coverage of the glacier geometry is insufficient to allow comparison of the surface slope and elevation before and after several surges.

The unusual behavior of the 1995 surge, which is still under investigation, might provide some additional insight into the surge initiation process and gives rise to some general speculations on the behavior of past surges. The termination of the first phase of the 1995 surge coincides with 2 days of record high temperatures, with the surge front still being located in the middle part of the glacier. At least until early summer 1997, no significant changes in the position of the surge front occurred. As a consequence, up to 1997 the surface in the upper glacier did not drop as much as after the 1983 surge; comparing the elevations at $\mathrm{F}-7$ 1 year after both surges, in 1996 the elevation was $20 \mathrm{~m}$ higher than in 1984. If the surface elevation plays a key role in surge initiation, the post-surge level of the 1995 surge, i.e. the surface elevation at F-7 in 1998, is likely to influence the length of the next surge interval. Due to the lower or higher surface elevation at F-7 (in reference to the 1983 elevation), reached after the final surge termination, either more or less accumulation would be necessary to trigger the next surge. On the other hand, if only the cumulative balance is important to initiate a surge, the next surge will probably be initiated around 2008, when the cumulative balance reaches the surge level (assuming a constant annual balance at $\mathrm{F}-7$ of $3.5 \mathrm{~m}$, the average from 1983-98).

The first scenario could also be applied to the 1922 surge, explaining the lower cumulative balances (Table 2). If its behavior was similar to the first phase of the 1995 surge, i.e. the surge terminated without the surge front having reached the terminus, less accumulation would be necessary to trigger the 1932 surge. Which of the above scenarios is more likely can be discussed in more detail after the next surge is observed.

The usefulness of the concept of a surge level depends upon how constant it is in time. Our results suggest that it is reasonably constant for Variegated Glacier, but it may depend somewhat upon the changing size of the glacier and other factors. The detection of a trend in the surge level would require a longer time series of surge observations and a more accurate estimate of the local annual balance series. Although the idea of a surge level has now been found to be useful on several glaciers, the approach has been largely empirical. The result is that the surge level for other glaciers must still be determined empirically rather than estimated on the basis of a physical understanding of the processes involved. Finally, a direct physical explanation for the length of the quiescent invervals has not been given, so our surge level cannot be used to explain the observed differences in the surge intervals of different glaciers.

\section{SUMMARY AND GONCLUSION}

The calculations carried out in this study are based on a series of accumulation measurements on Variegated Glacier, and the correlation with the climate record in Yakutat, Sitka and Cordova. The use of three weather stations is necessary to estimate missing Yakutat data in the first half of the 20th century. The initiation of the last three surges strongly correlates with the cumulative balance at our location to reach a reason- 
ably well-defined level of $43.5 \mathrm{~m}$. The period between the surges depends on the average annual balance at that point. A higher annual balance leads to a shorter surge interval, and vice versa. The hindcasting of surge events back to 1906, using the observed surge level, results in a total of six surges of Variegated Glacier during the 20th century, including an unobserved surge in 1922. The dating of the 1932 surge is confirmed by the dating obtained from photographs.

Besides the establishment of the connection between local annual balance and surge occurrence, the processes initially resulting in the onset of a surge cannot be identified. Data are too sparse to indicate other likely factors for surge initiation, such as surface slope and elevation. Neither does the surge-level hypothesis explain the behavior of a glacier during its surge, such as the occurrence of two phases during the 1983 surge, nor the two phases of a surge of Bering Glacier separated by 6 years (Post, 1972).

The results of this study form a base for further studies of unanswered problems of the processes starting a surge. The observation of the next surge of Variegated Glacier, together with the continuing calculation of the cumulative balance, should provide the opportunity to confirm or reject the hypothesis of a critical surge level, as well as furnishing better understanding of the reasons for and the effects of the unusual behavior of the 1995 surge.

\section{ACKNOWLEDGEMENTS}

We thank K. A. Echelmeyer and M. Truffer as well as T. Jóhannesson, T. Murray and O. Sigurðsson for their useful comments. Graphics were created using the Generic Mapping Tool (Wessel and Smith, 1991). The work was supported by U.S. National Science Foundation grant OPP-9977796 to the University of Alaska Fairbanks.

\section{REFERENCES}

Bindschadler, R. A., W. D. Harrison and C. F. Raymond. 1976. Variegated Glacier studies - 1975. Boulder, CO, National Snow and Ice Data Center (NSIDC).

Boulton, G. S. and A. S. Jones. 1979. Stability of temperate ice caps and ice sheets resting on beds of deformable sediment. F. Glaciol., 24(90), 29-43.

Braithwaite, R.J. 1985. Calculation of degree-days for glacier-climate research. Z. Gletscherkd. Glazialgeol., 20, 1984, 1-8.

Clarke, G. K. C., S. G. Collins and D. E. Thompson. 1984. Flow, thermal structure, and subglacial conditions of a surge-type glacier. Can. F. Earth Sci., 21 (2), 232-240.

Dowdeswell, J. A., R. Hodgkins, A.-M. Nuttall, J. O. Hagen and G. S. Hamilton. 1995. Mass balance change as a control on the frequency and occurrence of glacier surges in Svalbard, Norwegian High Arctic. Geophys. Res. Lett., 22(21), 2909-2912.

Dyurgerov, M. B., V. B. Aizin and A. B. Buynitskiy. 1985. Nakopleniye massy v oblasti pitaniya lednika Medvezh'yego za periody mezhdu yego podvizhkami [Mass accumulation in the accumulation area of Medvezhiy Glacier during its quiescence periods]. Mater. Glyatsiol. Issled. 54, 131-135.

Feher, S. A. 1976. Mapping of Variegated Glacier. (Ph.D. thesis, University of Washington.)

Fountain, A. G. and J. S. Walder. 1998. Water flow through temperate glaciers. Rev. Geophys., 36(3), 299-328.

Hanson, B. 1987. Reconstructing mass-balance profiles from climate for an Arctic ice cap. International Association of Hydrological Sciences Publication 170 (Symposium at Vancouver 1987 — The Physical Basis of Ice Sheet Modelling), 181-189.

Harrison, W. D., P. MacKeith and S. A. Ferguson. 1979. Magnetic markers for glacier mass balance and velocity measurements. Fairbanks, AK, University of Alaska. Geophysical Institute. (Report UAG-R-254.)

Harrison, W. D., K. A. Echelmeyer, E. F. Chacho, C. F. Raymond and R. J. Benedict. 1994. The 1987-88 surge of West Fork Glacier, Susitna Basin, Alaska, U.S.A. 7. Glaciol., 40(135), 241-254.

Hoinkes, H. and R. Steinacker. 1975. Hydrometeorological implications of the mass balance of Hintereisferner, 1952-53 to 1968-69. International Association of Hydrological Sciences Publication 104 (Symposium at Moscow 1971 - Snow and Ice), 144-149.

Kamb, B. 1987. Glacier surge mechanism based on linked cavity configuration of the basal water conduit system. 7. Geophys. Res., 92(B9), 9083-9100.

Kamb, B. and 7 others. 1985. Glacier surge mechanism: 1982-1983 surge of Variegated Glacier, Alaska. Science, 227(4686), 469-479.

Lawson, W. 1997. Spatial, temporal and kinematic characteristics of surges of Variegated Glacier, Alaska. Ann. Glaciol., 24, 95-101.

Letréguilly, A. 1988. Relation between the mass balance of western Canadian mountain glaciers and meteorological data. f. Glaciol., 34(116), 11-18.

Martin, S. 1974. Corrélation bilans de masse annuels - facteurs météorologiques dans les Grandes Rousses. Z. Gletscherkd. Glazialgeol., 10, 89-100.

National Oceanic and Atmospheric Administration (NOAA). 1999. Alaska climatological data, 1905-1999. Asheville, NC, U.S. Department of Commerce. National Oceanic and Atmospheric Administration. National Climatic Data Center. (Technical Report.)

Post, A. 1969. Distribution of surging glaciers in western North America. F. Glaciol., 8(53), 229-240.

Post, A. 1972. Periodic surge origin of folded medial moraines on Bering piedmont glacier, Alaska. F. Glaciol., 11(62), 219-226.

Rabus, B. T. and K. A. Echelmeyer. 1998. The mass balance of McCall Glacier, Brooks Range, Alaska, U.S.A.; its regional relevance and implications for climate change in the Arctic. F. Glaciol., 44(147), 333-351.

Raymond, C. F. 1987. How do glaciers surge? A review. 7. Geophys. Res., 92(B9), 9121-9134.

Raymond, C. F., W. D. Harrison, L. Gitomer, J. MacQueen, E. Senear and P. MacKeith. 1980. Variegated Glacier studies - 1978. Boulder, CO, National Snow and Ice Data Center (NSIDC).

Raymond, C. F., W. D. Harrison and E. Senear. 1981. Variegated Glacier studies 1979. Boulder, CO, National Snow and Ice Data Center (NSIDC).

Tangborn, W. 1980. Two models for estimating climate-glacier relationships in the North Cascades, Washington, U.S.A. F. Glaciol., 25(91), 3-21.

Tarr, R. S. and L. Martin. 1914. Alaskan glacier studies of the National Geographic Society in the Yakutat Bay, Prince William Sound and lower Copper River regions. Washington, DC, National Geographic Society.

Truffer, M., W. D. Harrison and K. A. Echelmeyer. 2000. Glacier motion dominated by processes deep in underlying till. f. Glaciol., 46(153), 213-221.

Wessel, P. and W. H. F. Smith. 1991. Free software helps map and display data. EOS, $72(41), 441,445-446$.

\section{APPENDIX}

\section{Reconstruction of climate record}

To reconstruct the Yakutat climate record, it is necessary to use data from the weather stations in Sitka and Cordova. The $P_{10-4}$ and $t_{5-9}$ series from all three stations are used to calculate the coefficients of a bilinear expression

$$
x^{\mathrm{YAK}}=c_{0}+c_{1} x^{\mathrm{SIT}}+c_{2} x^{\mathrm{COR}}
$$

and two simple linear regression formulae, using a leastsquares fit for 43 data points of the $1947-89$ series. $x$ is one of the climate series, $P_{10-4}$ or $t_{5-9}$, from the station indicated by the superscript.

The multiple correlation coefficients, similar to Equation (2), are 0.80 and 0.84 for the $t_{5-9}$ and $P_{10-4}$ series, respectively. A simple linear correlation between the corresponding meteorological variables of Yakutat and the other two stations results in a correlation coefficient of 0.41 for Sitka and 0.69 for Cordova in the case of $P_{10-4}$, and 0.79 for Sitka and 0.48 for Cordova for $t_{5-9}$. As the bilinear correlation yields the best correlation coefficient, we use Equation (4) to calculate the missing Yakutat minimum temperature and precipitation data when possible.

\section{Error of the annual balance series at F-7}

As mentioned in the text, the three different contributions to the errors of the extrapolated annual balance series at $\mathrm{F}-7$ - accuracy of the regression Equation (3), influence of the use of different weather stations, and the stability of the regression in time - are now discussed in detail. 


\section{Estimated error of the local annual balance regression}

As a measure of the error of the estimated annual balance at $\mathrm{F}-7, b_{\mathrm{a}}^{\mathrm{YAK}}(\mathrm{F}-7)$, in comparison to the original annual balance series, $b_{\mathrm{a}}^{\text {mes }}(\mathrm{F}-7)$, we calculate the rms error defined by

$$
\sigma_{\mathrm{rms}}^{\mathrm{mes}-\mathrm{YAK}}=\sqrt{\frac{1}{N-3} \sum_{i=1}^{N}\left[b_{\mathrm{a}}^{\mathrm{mes}}(\mathrm{F}-7)-b_{\mathrm{a}}^{\mathrm{YAK}}(\mathrm{F}-7)\right]^{2}},
$$

where $N$ is the number of data points. The rms error for the period $1973-82$ is $0.48 \mathrm{~m}$, or $18 \%$ of the mean of $b_{\mathrm{a}}^{\mathrm{mes}}(\mathrm{F}-7)$.

\section{Influence of the inhomogeneous database}

The error of the extrapolated annual balance at F-7 series before 1943 is quantitatively estimated using the Sitka and Cordova climate records for the period 1947-89. The Yakutat climate variables $P_{10-4}$ and $t_{5-9}$ are estimated from the regression Equation (4). The estimated climate series are then used in Equation (3) to calculate a second annual balance series at $\mathrm{F}-7$ for the period $1947-89$, which will be referred to as $b_{\mathrm{a}}^{\mathrm{SITCOR}}(\mathrm{F}-7)$. The rms error $\sigma_{\text {rms }}^{\text {mes-SITCOR }}=0.61 \mathrm{~m}, 22 \%$ of the average measured annual balance at $\mathrm{F}-7$. A better measure for the accuracy of the annual balances at $\mathrm{F}-7$ estimated from Sitka and Cordova records is the error $\sigma_{\text {rms }}^{\text {SITCOR-YAK, as }}$ it also includes the error of the regression Equation (3). For the $1947-89$ data, $\sigma_{\text {rms }}^{\text {SITCOR-YAK }}=0.78 \mathrm{~m}, 28 \%$ of the $b_{\mathrm{a}}^{\mathrm{YAK}}(\mathrm{F}-7)$ average.

The accuracy of the annual balance at $\mathrm{F}-7$ values solely estimated from the Sitka climate record is estimated applying the procedure just outlined to the Sitka record alone. As the Yakutat climate variables are then estimated from a linear regression, the denominator $N-3$ in Equation (5) is replaced by $N-2$. The errors are $\sigma_{\text {rms }}^{\text {mes-SIT }}=0.48 \mathrm{~m}$ and $\sigma_{\text {rms }}^{\text {SIT }- \text { YAK }}=0.78 \mathrm{~m}$. Eventually the following errors are assigned to the extrapolated annual balance series at $\mathrm{F}-7$ : $\sigma_{\text {rms }}^{\text {SITCOR-YAK }}=0.48 \mathrm{~m}$ for the values estimated from the Yakutat record; $\sigma_{\text {rms }}^{\text {SITCOR-YAK }}$ and $\sigma_{\text {rms }}^{\text {SIT-YAK }}$, both $0.78 \mathrm{~m}$, where Cordova and/or Sitka records are used (Fig. 4).

\section{Stability of the regression}

No other annual balance data for Variegated Glacier, neither local nor for the whole glacier, are currently available to test if the regression Equation (3) leads to the same rms error for other time periods, i.e. if it is stable in time. With 10 data points the measured time series is also too short to derive several regression formulae from time-frames which are shorter than the complete series, and to compare the results of the different regressions. However, the variations in the annual balances at F-7 from 1973-82 are quite large. They range from $1.1 \mathrm{~m}$ in 1974 to $4.6 \mathrm{~m}$ in 1977. This implies that several different states of the circulation over the Gulf of Alaska were observed and recorded during the 10 year measurement period. We therefore assume that the local annual balances at F-7 obtained from Equation (3) using Yakutat meteorological data are also representative for other years.

A quantitative estimate uses $\sigma_{\text {rms }}^{\text {SITCOR-YAK }}$ and $\sigma_{\text {rms }}^{\text {SIT-YAK }}$ to evaluate the stability of the regression Equation (3) for the time after 1943 . Both errors are only about $60 \%$ larger than $\sigma_{\text {rms }}^{\text {mes-YAK }}$, and not more than $30 \%$ larger than $\sigma_{\text {rms }}^{\text {mes-SITCOR }}$. It can therefore be concluded that the relations among the different weather stations and the annual balance at $\mathrm{F}-7$ established above for the period 1973-82 are also valid for the period after 1943 . 